Check for updates

Cite this: RSC Adv., 2018, 8, 11997

\title{
Magnetic carbon nanotubes for self-regulating temperature hyperthermia $\dagger$
}

\author{
Xudong Zuo, ${ }^{a}$ Chengwei Wu, ${ }^{a}$ Wei Zhang (D)*a and Wei Gao ${ }^{b}$
}

Magnetic hyperthermia can enhance the anti-tumor effects of chemotherapy. As carbon nanotubes are ideal drug carriers for chemotherapy, their combination with magnetic nanoparticles provides a novel chance for multi-modal thermo-chemotherapy. Most related work focuses on attaching $\mathrm{Fe}_{3} \mathrm{O}_{4}$ nanoparticles on carbon nanotubes, however the hyperthermia temperature for this combination can not be self-regulated due to the high Curie temperature of $\mathrm{Fe}_{3} \mathrm{O}_{4}$. In this work, magnetic $\mathrm{Zn}_{0.54} \mathrm{CO}_{0.46} \mathrm{Cr}_{0.6} \mathrm{Fe}_{1.4} \mathrm{O}_{4}$ nanoparticles with low Curie temperature were attached onto carbon nanotubes to obtain the magnetic carbon nanotubes. The morphology, formation mechanism, magnetic properties, heat generation ability and cytotoxicity of the magnetic carbon nanotubes were investigated. These magnetic carbon nanotubes show a Curie temperature of $43^{\circ} \mathrm{C}$ and a self-regulating temperature at $42.7^{\circ} \mathrm{C}$ under clinically applied magnetic field conditions (frequency: $100 \mathrm{kHz}$, intensity: $200 \mathrm{Oe}$ ). The evaluation of in vitro cytotoxicity suggests no obvious toxicity effects under the concentrations of 6.25 $\mu \mathrm{g} \mathrm{ml}^{-1}$ to $100 \mu \mathrm{g} \mathrm{ml}^{-1}$. This study proposed a methodology for the bespoke synthesis of magnetic carbon nanotubes with a low Curie temperature for self-regulating magnetic hyperthermia, which may be used for further research on loading drugs for multi-modal cancer therapy.

Received 12th December 2017

Accepted 17th March 2018

DOI: $10.1039 / \mathrm{c} 7 \mathrm{ra13256e}$

rsc.li/rsc-advances molecules in blood and enhance cellular uptake of the drug by cancer cells. ${ }^{13-16}$ Graphic surface of CNTs can also be modified in order to graft specific antibodies, avoiding immune action and reducing the possibilities of undesired cytotoxicity. ${ }^{17}$ These fascinating properties make CNTs emerge as promising therapy-enhancing nanomaterials.

Hyperthermia can enhance the anti-tumor effects of chemotherapy by increasing the uptake of carcinostatics into tumor cells and inhibiting the repair of tumor cells. ${ }^{18,19}$ The dose of anti-tumor drugs, therefore, can be decreased by the combination with hyperthermia, and the undesirable side effects of chemotherapy drugs can be also minimized. As CNTs are ideal carriers of drugs, their combination of magnetic nanoparticles may provide a possibility for further research on multi-modal thermos-chemotherapy. However, most of related work focus on attaching $\mathrm{Fe}_{3} \mathrm{O}_{4}$ nanoparticles on CNTs, but the hyperthermia temperature in vivo is hard to monitor and control. And a temperature higher than $45{ }^{\circ} \mathrm{C}$ may cause damage to normal tissue..$^{\mathbf{2 0} 21}$

Tuning the Curie temperature of magnetic media to a value just above the treatment temperature is considered as an expedient route to control the magnetic hyperthermia temperature and realize self-regulation. ${ }^{22-25}$ Curie temperature is the temperature at which ferromagnetic materials lose their intrinsic permanent magnetic properties and consequently lose their ability to generate heat under alternating magnetic field. The Curie temperature therefore gives an upper limit to the operational temperature for the magnetic media. In the present

\footnotetext{
${ }^{a}$ State Key Laboratory of Structural Analysis for Industrial Equipment, Department of Engineering Mechanics, Dalian University of Technology, Dalian 116024, P. R. China. E-mail:wei.zhang@dlut.edu.cn

${ }^{b}$ Department of Chemical and Materials Engineering, The University of Auckland, Auckland 1142, New Zealand

$\dagger$ Electronic supplementary information (ESI) available: Table S1-the theoretical and measured element ratios of MNPs and MCNTs, Fig. S1-UV-vis spectra of MNPs and MCNTs aqueous solution at the moment of dispersion and after 12 h. See DOI: $10.1039 / \mathrm{c} 7 \mathrm{ra13256e}$
} 
work, we prepared magnetic nanoparticles $\left(\mathrm{Zn}_{0.54} \mathrm{Co}_{0.46} \mathrm{Cr}_{0.6}\right.$ $\mathrm{Fe}_{1.4} \mathrm{O}_{4}$ ) with Curie temperature at $45.7^{\circ} \mathrm{C}$ and successfully decorated them on the surface of CNTs through hydrothermal method. Magnetic carbon nanotubes (MCNTs) with Curie temperature at $43{ }^{\circ} \mathrm{C}$ were obtained. These MCNTs show a Curie temperature of $43{ }^{\circ} \mathrm{C}$ and self-regulating temperature at $42.7^{\circ} \mathrm{C}$ under clinically applied magnetic field conditions (frequency: $100 \mathrm{kHz}$, intensity: $200 \mathrm{Oe}$ ), which is suitable for hyperthermia use. Compared with pure nanoparticles, MCNTs have a better dispersive ability to avoid the inhomogeneous temperature distribution caused by the aggregation of nanoparticles. This study proposed a method on the bespoke synthesis of MCNTs with low Curie temperature for self-regulating magnetic hyperthermia, which may be used of further research on loading drugs for multi-modal cancer therapy.

\section{Experimental}

\section{Chemical synthesis}

$\mathrm{FeCl}_{3} \cdot 6 \mathrm{H}_{2} \mathrm{O}(99 \%+)$ and $\mathrm{CrCl}_{3} \cdot 6 \mathrm{H}_{2} \mathrm{O}(99 \%+)$ were obtained from Shantou Xilong Chemical Co. Ltd., China. $\mathrm{CoCl}_{2} \cdot 6 \mathrm{H}_{2} \mathrm{O}$ $(99 \%+)$ and $\mathrm{NaOH}(96 \%+)$ were supplied by Tianjin Bodi Chemical Co. Ltd., China. $\mathrm{ZnCl}_{2}(98 \%+)$ was supplied by Tianjin Damao Chemical Co. Ltd., China. Carboxylic multi-walled CNTs were purchased from Shenzhen Nanotech Port Co. Ltd., China. $\mathrm{CrCl}_{3} \cdot 6 \mathrm{H}_{2} \mathrm{O}(3.3 \mathrm{mmol}), \mathrm{FeCl}_{3} \cdot 6 \mathrm{H}_{2} \mathrm{O}(7.7 \mathrm{mmol}), \mathrm{CoCl}_{2} \cdot 6 \mathrm{H}_{2} \mathrm{O}$ $(2.53 \mathrm{mmol}), \mathrm{ZnCl}_{2}(2.97 \mathrm{mmol})$ and carboxylic CNTs $(0.75 \mathrm{~g})$ were dissolved in $80 \mathrm{ml}$ deionized water under stirring for $1 \mathrm{~h}$. Then the $\mathrm{NaOH}$ solution $\left(0.5 \mathrm{~mol} \mathrm{~L}^{-1}, 150 \mathrm{ml}\right)$ was slowly dropped into the metal salts solution with vigorous stirring for $30 \mathrm{~min}$ to form the precursor. The precursor was sealed in autoclave and heated to $250{ }^{\circ} \mathrm{C}$ (heating rate: $2.3{ }^{\circ} \mathrm{C} \mathrm{min}$ ), maintained for $2 \mathrm{~h}$ and then allowed to cool to room temperature. The products were washed with deionized water and ethanol till neutral, and then dried at $60^{\circ} \mathrm{C}$ for $6 \mathrm{~h}$ in a vacuum drying chamber. Magnetic nanoparticles (MNPs) were also synthesized through the same way without adding carboxylic CNTs for comparison purpose.

\section{Characterization}

The crystal structure was characterized by PANalytical Empyrean X-ray diffractometer (XRD) (Netherlands) with $\mathrm{Cu} \mathrm{K} \alpha$ radiation $(\lambda=0.15406 \mathrm{~nm})$. The Raman analysis was conducted on a Renishaw Invia Laser Raman Spectrometer (UK) with a green laser $(\lambda=532 \mathrm{~nm})$ incitation. Fourier transform infrared spectroscopy (FTIR) data were collected on a NEXUS $670 \mathrm{spec}-$ trometer. The transmission electron microscope (TEM) images were obtained on a FEI Tecnai G2 F30 (USA). Magnetization curves were recorded at $300 \mathrm{~K}$ on a Jilin University JDM-13 vibrating sample magnetometer (China).

The Curie temperature was measured by thermogravimetric analysis (TGA) using Mettler-Toledo TGA 851 (Switzerland) with a Nd-Fe-B magnet $\left(100 \times 50 \times 5 \mathrm{~mm}^{3}\right)$ placed up over the samples about $10 \mathrm{~cm}$. When the temperature is below Curie temperature, the weights of MCNTs recorded by TGA are less than real weights due to the attractive magnetic force between
MCNTs and the magnet. When temperature increases to the Curie point, the MCNTs loses their magnetism and the weight becomes the real weight. The transition point is the Curie temperature.

The time-dependent temperature curves were determined by calorimetric measurements. The experimental setup is illustrated in Fig. 1. To make the performance of MCNTs under the alternating magnetic field closer to the clinic treatment, the experimental condition was set up as the same as Jordan's clinical treatment. ${ }^{26,27}$ All the MCNTs suspension were dispersed into deionized water with the same concentration $\left(112 \mathrm{mg} \mathrm{ml}^{-1}\right.$ ), and the frequency and intensity of the magnetic field are set to $100 \mathrm{kHz}$ and $200 \mathrm{Oe}$, respectively. Once being irradiated, the temperature of suspension was measured by an alcohol thermometer at $60 \mathrm{~s}$ intervals.

\section{Cell culture and cytotoxicity assay}

Human epidermal keratinocyte (HaCaT) cells were purchased from China Center for Type Culture Collection (Wuhan) and maintained in high glucose Dulbecco's Modified Eagle Medium (DMEM) (Gibco, USA) in a humidified $37^{\circ} \mathrm{C}$ incubator (Thermos HERAcell150, USA) at $5 \% \mathrm{CO}_{2}$ supplemented with $10 \%$ fetal bovine serum (FBS) (Gibco, USA) and 1\% penicillin-streptomycin (Gibco, USA). After sterilized with $75 \%$ (v/v) ethanol/ deionized water for $24 \mathrm{~h}$ and rinsed with phosphate buffer saline (PBS) three times, the MCNTs were suspended in cell culture medium with a concentration of $0 \mu \mathrm{g} \mathrm{ml} \mathrm{m}^{-1}, 6.25 \mu \mathrm{g}$ $\mathrm{ml}^{-1}, 12.5 \mu \mathrm{g} \mathrm{ml} \mathrm{g}^{-1}, 25 \mu \mathrm{g} \mathrm{ml}^{-1}, 50 \mu \mathrm{g} \mathrm{ml}^{-1}$ and $100 \mu \mathrm{g} \mathrm{ml} \mathrm{g}^{-1}$. HaCaT cells were seeded in 24-well plates and 96-well plates with a density of $5 \times 10^{4}$ cells per $\mathrm{ml}$ for evaluation of in vitro cytotoxicity of MCNTs.

The quantitative evaluation of in vitro cytotoxicity of MCNTs against HaCaT cells were performed by using the cell counting kit-8 (CCK-8) assay (Dojindo Laboratories Kumamoto, Japan). HaCaT cells were seeded in 96-well plates with a density of $5 \times$ $10^{4}$ cells per ml. After $3 \mathrm{~h}$ of culture, adherent cells were exposed to the fresh culture medium containing $0 \mu \mathrm{g} \mathrm{ml} \mathrm{m}^{-1}$ (control), 6.25 $\mu \mathrm{g} \mathrm{ml} l^{-1}, 12.5 \mu \mathrm{g} \mathrm{ml}^{-1}, 25 \mu \mathrm{g} \mathrm{ml}^{-1}, 50 \mu \mathrm{g} \mathrm{ml} \mathrm{m}^{-1}$ and $100 \mu \mathrm{g} \mathrm{ml}^{-1}$ MCNTs. At $24 \mathrm{~h}, 48 \mathrm{~h}$ and $72 \mathrm{~h}$, the cell viability was assessed. The culture medium was briefly refreshed, and $10 \mu \mathrm{l} \mathrm{CCK-8}$ was added to each well containing $100 \mu \mathrm{l}$ new medium. After incubated in dark at $37{ }^{\circ} \mathrm{C}$ for $2 \mathrm{~h}, 100 \mu \mathrm{l}$ of each MCNTs solution was transferred to a new 96-well plate to measure the absorbance of the formazan product at $450 \mathrm{~nm}$ by using a microplate

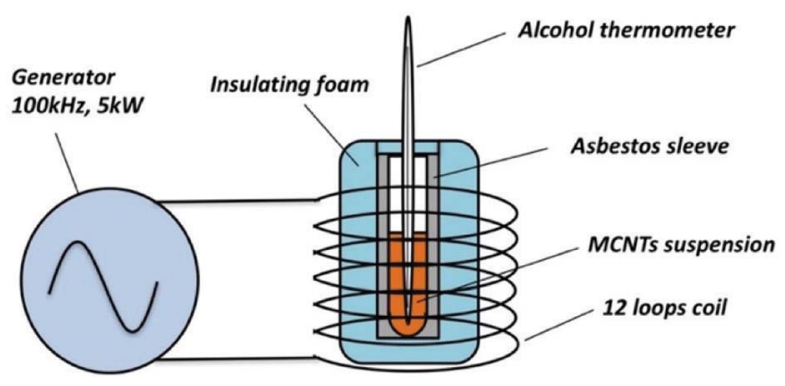

Fig. 1 The experimental setup of calorimetric measurements. 
reader (SPECTRAFLUOR, TECAN, Sunrise, Austria). The cell viability was calculated through formula (1):

Viability $(\%)=\left[\mathrm{OD}_{\text {nanoparticles }}-\mathrm{OD}_{\text {blank }}\right] /$

$$
\left[\mathrm{OD}_{\text {control }}-\mathrm{OD}_{\text {blank }}\right] \times 100 \%
$$

where $\mathrm{OD}_{\text {nanoparticles }}$ is the optical density of the well containing various concentration of nanoparticles, DMEM medium and cells. $\mathrm{OD}_{\text {control }}$ is the optical density of the well containing DMEM medium and cells. $\mathrm{OD}_{\text {blank }}$ is the optical density of the well only containing DMEM medium.

In addition, cell viability was observed by staining with Calcein-AM, Hochest 33258, and propidium iodide (PI). After $72 \mathrm{~h}$ of culture, cells were rinsed with PBS for three times and stained with PBS containing $2 \mu \mathrm{mol} \mathrm{L}{ }^{-1}$ Calcein-AM, $5 \mu \mathrm{g} \mathrm{ml}^{-1}$ Hochest 33258, and $4 \mu \mathrm{mol} \mathrm{L}^{-1}$ PI (Sigma, Mo, USA). After incubated in dark at $37^{\circ} \mathrm{C}$ for $15 \mathrm{~min}$, cells were rinsed with PBS for three times. Then the viable and dead cells were imaged using a fluorescent microscope (OLYMPUS BX71, Japan).

\section{Results and discussion}

The size, morphology and crystalline information have been investigated by TEM, XRD, Raman and FTIR analysis, given in Fig. 2. Fig. 2a and d show the representative TEM images of MCNTs and MNPs respectively. Inset of Fig. $2 \mathrm{~d}$ shows the size distribution of $\mathrm{Zn}_{0.54} \mathrm{Co}_{0.46} \mathrm{Cr}_{0.6} \mathrm{Fe}_{1.4} \mathrm{O}_{4}$ nanoparticles, which is obtained from 100 nanoparticles. The mean edge length of the nanoparticles is found to be $30.3 \mathrm{~nm}$. After adding CNTs, the nanoparticles were successfully decorated on the surface of CNTs. To identify the actual concentration of $\mathrm{Zn}_{0.54} \mathrm{Co}_{0.46} \mathrm{Cr}_{0.6}$ $\mathrm{Fe}_{1.4} \mathrm{O}_{4}$ in MCNTs, we heated MCNTs at $800{ }^{\circ} \mathrm{C}$ for $2 \mathrm{~h}$ in air to remove CNTs and then the weight percent of $\mathrm{Zn}_{0.54} \mathrm{Co}_{0.46} \mathrm{Cr}_{0.6^{-}}$ $\mathrm{Fe}_{1.4} \mathrm{O}_{4}$ in MCNTs is calculated, which is around $73.5 \%$. To obtain the detailed crystalline information of MCNTs, HRTEM and XRD were performed. Fig. $2 \mathrm{~b}$ shows the interlayer distances of MCNTs are $0.245 \mathrm{~nm}$ and $0.349 \mathrm{~nm}$, corresponding to the lattice planes (311) in spinel nanoparticles and (002) in CNTs.
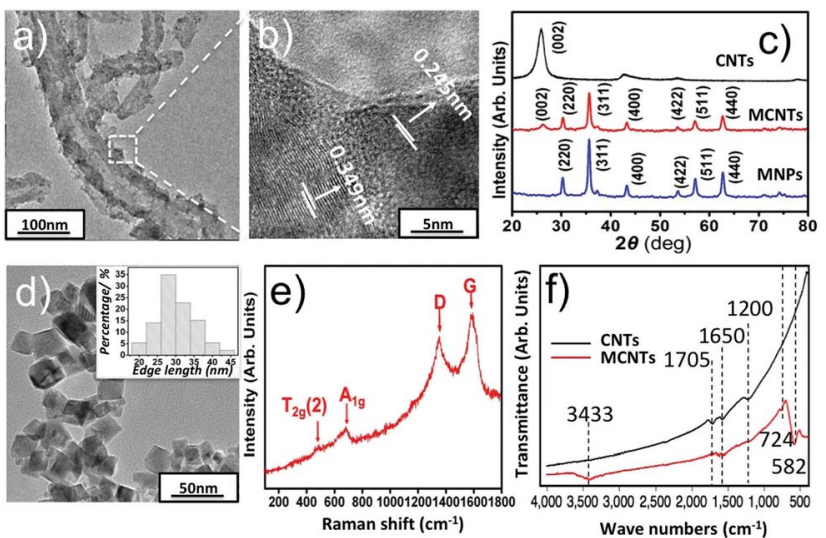

Fig. 2 (a) TEM image of MCNTs; (b) HRTEM image of MCNTs; (c) XRD patterns of carboxylic CNTs, MCNTs and MNPs; (d) TEM image of MNPs; (e) Raman spectra of MCNTs; (f) FTIR spectra of MCNTs and carboxylic CNTs.
Fig. $2 \mathrm{c}$ shows the XRD phase analysis. Patterns of MNPs can be easily indexed to cubic spinel structure of $\mathrm{CoFe}_{2} \mathrm{O}_{4}{ }^{-}$ $\mathrm{CoCrFe}_{2} \mathrm{O}_{4}$ (JCPDS-ICDD, 03-0864); and no obvious XRD peaks from impurities could be observed. Compared with MNPs, the patterns of MCNTs have an extra peak (002) arising from CNTs. ${ }^{28}$ The element information was determined by an Electron-Probe Microanalyzer. The results, together with the molar ratio of metal elements initially added, are given in Table 1s. $\dagger$ Clearly, all metal elements in the samples do not deviate significantly from their initial stoichiometry. Based on the Electron-Probe Microanalyzer and XRD experiments, it could be concluded that the all the metal ions successfully enter the lattice. The Raman spectra of MCNTs are given in Fig. 2e. D and $\mathrm{G}$ bands at $1346 \mathrm{~cm}^{-1}$ and $1575 \mathrm{~cm}^{-1}$ correspond to the $\mathrm{sp}^{3}$ and $\mathrm{sp}^{2}$ hybridized carbons respectively, ${ }^{29}$ arising from CNTs. Peak at $477 \mathrm{~cm}^{-3}$ is assigned to $T_{2 g}(2)$ mode, corresponding to the local symmetry vibrations of metal ions in the octahedral site of spinel nanoparticles. ${ }^{30}$ Peak at $678 \mathrm{~cm}^{-1}$ is related to $A_{1 g}$ mode arising from the stretching vibrations of $\mathrm{Fe}^{3+}$ and $\mathrm{O}^{2-}$ in the tetrahedral site in spinel nanoparticles. ${ }^{31}$ These active vibration modes show the spinel structure of nanoparticles attached on CNTs. A combination of TEM, XRD and Raman spectra analyses confirm the crystalline structure of MCNTs.

To have a clear observation of the changes in functional groups on MCNTs, FTIR was performed. As shown in Fig. 2f, compared with the spectra of carboxylic CNTs, the band peaks at $582 \mathrm{~cm}^{-1}, 3433 \mathrm{~cm}^{-1}$ appeared and peaks at $1200 \mathrm{~cm}^{-1}$, $1705 \mathrm{~cm}^{-1}$ vanished on MCNTs. The appearance of peaks at $582 \mathrm{~cm}^{-1}$ could be assigned to the stretching vibration of the metal-oxygen bond at tetrahedral site in spinel structure of $\mathrm{Zn}_{0.54} \mathrm{Co}_{0.46} \mathrm{Cr}_{0.6} \mathrm{Fe}_{1.4} \mathrm{O}_{4}$ nanoparticles, formed on the surface of CNTs. ${ }^{32}$ The appearance of a broad peak at $3433 \mathrm{~cm}^{-1}$ indicates the existence of hydroxyl group on MCNTs, which may be induced from alkaline solution during the hydrothermal process. ${ }^{33}$ The bands at $1200 \mathrm{~cm}^{-1}, 1705 \mathrm{~cm}^{-1}$ and $724 \mathrm{~cm}^{-1}$ are all attributed to the carboxylic group on CNTs, corresponding to the bending of $\mathrm{C}-\mathrm{O}$ bond, stretching and bending vibration of $\mathrm{C}=\mathrm{O}$ bond respectively. Compared with CNTs, the disappearance of $1705 \mathrm{~cm}^{-1}, 1200 \mathrm{~cm}^{-1}$ and the appearance of $724 \mathrm{~cm}^{-1}$ on MCNTs shows change of carboxylic group, which mainly results from the formation of either a monodentate complex or a bidentate complex between the carboxyl group and metal atoms on the surface of nanoparticles. ${ }^{34}$ These spectroscopic changes support that the nanoparticles are covalently bound to the carboxylic CNTs.

The formation mechanism of MCNTs was investigated and proposed, as depicted in Fig. 3a. The carboxyl groups on the surface of CNTs provide sites for the nucleation and growth of nanoparticles. In this experiment, after dissolving the carboxylic CNTs into metal salt solution, the metal ions $\mathrm{Zn}^{2+}, \mathrm{Co}^{2+}$, $\mathrm{Fe}^{3+}$ and $\mathrm{Cr}^{3+}$ ) are preferentially absorbed on these sites due to the electrostatic force. When a $\mathrm{NaOH}$ solution is added, the precursors, metal hydroxides attached on the CNTs, form. With increasing temperature, dehydration reactions take place on $\mathrm{Co}(\mathrm{OH})_{2}$ and yields crystallized $\mathrm{CoO}$. This $\mathrm{CoO}$ serves as the basis for the formation of $\mathrm{Zn}_{0.54} \mathrm{Co}_{0.46} \mathrm{Cr}_{0.6} \mathrm{Fe}_{1.4} \mathrm{O}_{4}$ nanoparticles on CNTs by either heterogeneous nucleation or homogeneous 

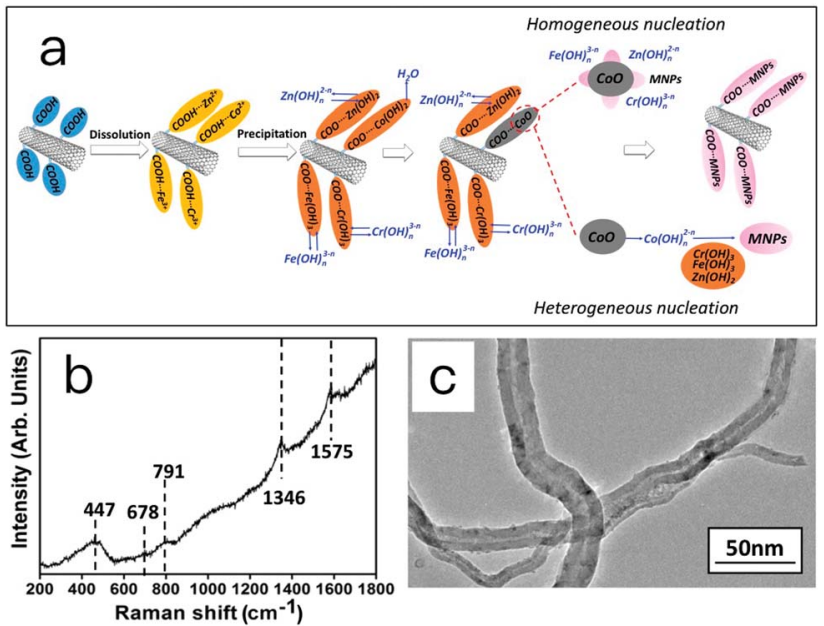

Fig. 3 Formation mechanism of MCNTs. (a) Proposed formation mechanism of MCNTs; (b) Raman spectra of precursor MCNTs taken at $100^{\circ} \mathrm{C}$; (c) TEM image of magnetic carbon nanotubes prepared using pristine carbon nanotubes.

nucleation. In the heterogeneous nucleation pathway, ions or ionomers such as $\mathrm{Fe}(\mathrm{OH})_{n}{ }^{3-n}, \mathrm{Cr}(\mathrm{OH})_{n}{ }^{3-n}$ and $\mathrm{Zn}(\mathrm{OH})_{n}{ }^{2-n}$ dissolve from the hydroxide and adsorb onto the surface of crystal CoO. Crystalline spinel $\mathrm{Zn}_{0.54} \mathrm{Co}_{0.46} \mathrm{Cr}_{0.6} \mathrm{Fe}_{1.4} \mathrm{O}_{4}$ forms on the surface of crystal $\mathrm{CoO}$ through dehydration and molecular rearrangement. Within the homogeneous nucleation pathway, the $\mathrm{Co}-\mathrm{O}$ bond may break due to the attack of $\mathrm{H}_{2} \mathrm{O}$ molecules, and form a complex cobalt ion $\mathrm{Co}(\mathrm{OH})_{n}{ }^{2-n}$ and dissolve into the solution. The $\mathrm{Fe}(\mathrm{OH})_{3}, \mathrm{Cr}(\mathrm{OH})_{3}$ and $\mathrm{Zn}(\mathrm{OH})_{2}$ attached on the CNTs then react with $\mathrm{Co}(\mathrm{OH})_{n}{ }^{2-n}$ and forms $\mathrm{Zn}_{0.54} \mathrm{Co}_{0.46} \mathrm{Cr}_{0.6^{-}}$ $\mathrm{Fe}_{1.4} \mathrm{O}_{4}$ crystals. In this proposed mechanism, the generation of $\mathrm{CoO}$ and the existence of carboxylic groups on CNTs are essential.

To obtain evidence for the proposed mechanisms, two experiments were conducted. Raman spectroscopy is the first one to characterize the structure of precursor taken at $100{ }^{\circ} \mathrm{C}$. The result is given in Fig. 3b. Raman modes at 1346 and $1575 \mathrm{~cm}^{-1}$ could be attributed to the D band and $\mathrm{G}$ band of CNTs. The other three Raman modes at 791, 678 and $447 \mathrm{~cm}^{-1}$ are assigned to $\mathrm{CoOOH}, \mathrm{Zn}_{0.54} \mathrm{Co}_{0.46} \mathrm{Cr}_{0.6} \mathrm{Fe}_{1.4} \mathrm{O}_{4}$ and $\mathrm{CoO}$, respectively. ${ }^{35}$ In the Raman spectra of MCNTs (Fig. 2e), however, the peaks of $\mathrm{CoO}$ and $\mathrm{CoOOH}$ disappeared, and the peaks of $\mathrm{Zn}_{0.54} \mathrm{Co}_{0.46} \mathrm{Cr}_{0.6} \mathrm{Fe}_{1.4} \mathrm{O}_{4}$ are enhanced. This supports the aforementioned mechanism in that the $\mathrm{CoO}, \mathrm{Zn}_{0.54} \mathrm{Co}_{0.46^{-}}$ $\mathrm{Cr}_{0.6} \mathrm{Fe}_{1.4} \mathrm{O}_{4}$ and $\mathrm{Co}(\mathrm{OH})_{n}{ }^{2-n}$ coexist in the reaction system, and finally $\mathrm{CoO}$ and $\mathrm{Co}(\mathrm{OH})_{n}{ }^{2-n}$ are all transformed into $\mathrm{Zn}_{0.54} \mathrm{Co}_{0.46} \mathrm{Cr}_{0.6} \mathrm{Fe}_{1.4} \mathrm{O}_{4}$.

In the second experiment, pristine multi-walled carbon nanotubes without any functional groups were used to prepared magnetic carbon nanotubes. Fig. 3c shows the TEM image of magnetic carbon nanotubes. No magnetic nanoparticles were found attached on the surface of carbon nanotubes. This supports the proposed mechanism that carboxylic groups provide sites for the nucleation and growth of nanoparticles due to the electrostatic force, and nanoparticles cannot attach on the surface of carbon nanotubes without carboxylic groups.

The magnetic properties of MNPs and MCNTs were displayed in Fig. 4. Room temperature $(300 \mathrm{~K})$ magnetization hysteresis loops were shown in Fig. 4a. The coercivity $\left(H_{c}\right)$ and saturation magnetization $\left(M_{\mathrm{s}}\right)$ of MCNTs are 129 Oe and $15 \mathrm{emu}$ $\mathrm{g}^{-1}$ respectively, which is lower than that of MNPs (172 Oe and $34 \mathrm{emu} \mathrm{g}^{-1}$ ). The difference of $H_{\mathrm{c}}$ and $M_{\mathrm{s}}$ mainly attributes the addition of nonmagnetic CNTs, which decrease the magnetic moment per unit mass.

The thermogravimetric curves are shown in Fig. $4 \mathrm{~b}$. As the temperature increases, the nominal weight of MNPs and MCNTs both increase initially, which means that the magnetization decrease with increasing temperature. When the temperature exceeds the Curie temperature, the nominal weight will not change. It is also observed that the temperature range of losing magnetization is broad. This is caused by the individual size differences of nanoparticles. According to Nikolaev's research, ${ }^{36}$ the Curie temperature is directly proportional to the bulk density of exchange bonds. The thickness of surface layer increases with decreasing particle radius. Since the number of exchange bonds at the surface layer is less than that at the particle core, the smaller the nanoparticle size, the lower the Curie temperature. Thus, the temperature range of losing magnetization may be influenced by the size distribution of nanoparticles.

When the temperature reaches the Curie point of a majority of nanoparticles, it experiences the most rapid weight increase in the curves, and the Curie temperature can be determined by taking the maximum value of the first derivative of the thermogravimetric curves. The Curie points of MNPs and MCNTs
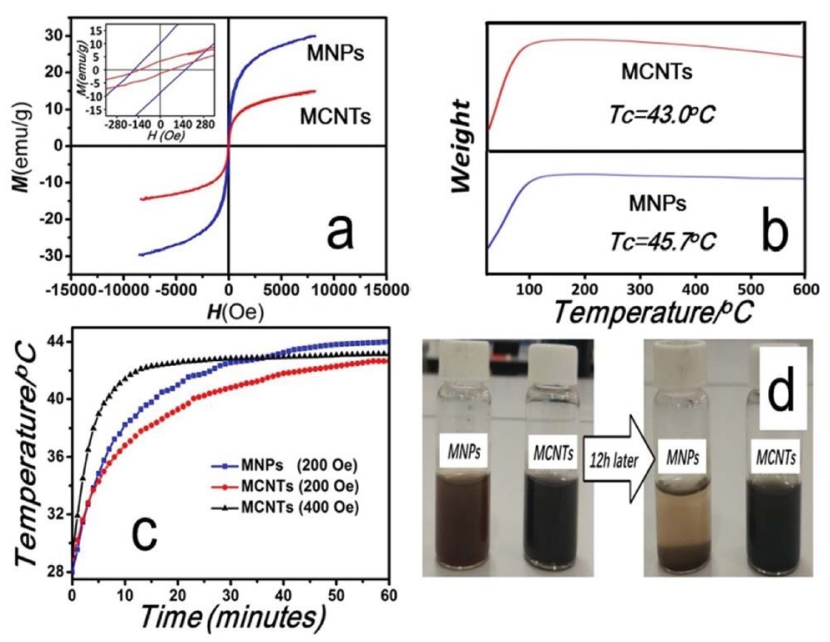

Fig. 4 Magnetic properties and dispersibility of MCNTs and MNPs. (a) Magnetization curves of MNPs and MCNTs. The $H_{c}$ and $M_{s}$ of MCNTs are $129 \mathrm{Oe}$ and $15 \mathrm{emu} \mathrm{g}^{-1}$ respectively, which are lower than that of MNPs (172 Oe and $34 \mathrm{emu} \mathrm{g}^{-1}$ ). (b) Thermogravimetric curves of MCNTs and MNPs. The Curie temperature of MNPs and MCNTs are $45.7{ }^{\circ} \mathrm{C}$ and $43.0^{\circ} \mathrm{C}$ respectively. (c) Time-dependent temperature curves of MNPs and MCNTs in $100 \mathrm{kHz}$ alternating magnetic field (blue line and red line: 200 Oe; Black line: 400 Oe). MCNTs with Curie temperature at $43{ }^{\circ} \mathrm{C}$ result in the self-regulating temperature of MCNTs suspension at hyperthermia temperature (around $43^{\circ} \mathrm{C}$ ). (d) MNPs and MCNTs dispersed in aqueous solution. 
are decided as $45.7{ }^{\circ} \mathrm{C}$ and $43.0^{\circ} \mathrm{C}$ respectively. Compared with MNPs, the TGA curves of MCNTs shows a slight thermal degradation when the temperature increases over $200{ }^{\circ} \mathrm{C}$. This weight loss is mainly attributed to the decarboxylation of the carboxylic groups present on the CNTs. ${ }^{37}$

The time-dependent temperature curves of MNPs and MCNTs suspensions were determined by calorimetric measurements. MNPs and MCNTs were dispersed into deionized water with the same concentration $\left(112 \mathrm{mg} \mathrm{ml}^{-1}\right)$ before exposure to the external alternating magnetic fields (200 Oe, 100 $\mathrm{kHz}$ ), which is applicable to clinical therapy. ${ }^{26,27}$ As can be seen in Fig. 4c (blue line and red line), after being irradiated for $60 \mathrm{~min}$, the temperature of suspension could rise to $44.0^{\circ} \mathrm{C}$ and $42.7^{\circ} \mathrm{C}$ respectively. In order to evaluate heat efficiency quantitatively, specific absorption rate (SAR) under alternating magnetic fields, which describes the energy converted into heat per time and mass, was calculated using the formula (2): ${ }^{38}$

$$
\mathrm{SAR}=C(\mathrm{~d} T / \mathrm{d} t)\left(m_{\mathrm{s}} / m_{\mathrm{m}}\right)
$$

where $C$ is the specific heat capacity of suspension $\left(4.18 \mathrm{~J} \mathrm{gK}^{-1}\right)$; $\mathrm{d} T / \mathrm{d} t$ is the slope of the time-dependent temperature curve; $m_{\mathrm{s}}$ is the mass of suspension and $m_{\mathrm{m}}$ is the mass of magnetic media in the suspension. As the temperature higher than room temperature will cause heat loss to surroundings which may significantly influence value of SAR, ${ }^{39,40}$ here we calculated SAR just at room temperature and select $\mathrm{d} T / \mathrm{d} t$ at the initial several seconds of the experiment, when heat transfer to surroundings can be ignored. The SAR of MNPs and MCNTs are $774 \mathrm{~W} \mathrm{~kg}^{-1}$ and $695 \mathrm{~W} \mathrm{~kg}^{-1}$ respectively. As the $H_{\mathrm{c}}$ and $M_{\mathrm{S}}$ of MCNTs are lower than that of MNPs, the area of hysteresis loop of MCNTs is smaller than that of MNPs, which result in lower heat efficiency of MCNTs.

After a rapid increase of temperature, the MNPs and MCNTs suspensions reach a stable temperature of $44.0^{\circ} \mathrm{C}$ and $42.7^{\circ} \mathrm{C}$, which is close to their Curie temperatures $\left(45.7^{\circ} \mathrm{C}\right.$ and $\left.43.0^{\circ} \mathrm{C}\right)$. To investigate the ability of self-regulating temperature of MCNTs, additional magnetic heating experiment with higher SAR has been conducted. Here, time-dependent temperature curve under the magnetic field of 400 Oe is recorded and the result is given in Fig. 4c (black line). Although SAR is much higher (1372 $\left.\mathrm{W} \mathrm{kg}^{-1}\right)$, MCNTs suspensions reach the stable temperature of $43.1^{\circ} \mathrm{C}$, still fairly close to the stable temperature under 200 Oe and Curie temperature. Only when the hyperthermia temperature is maintained below the Curie point, MCNTs keeps their magnetism and generate sufficient heat under an alternating magnetic field in this self-regulating system. Otherwise, the magnetic media will lose their magnetism and not generate heat, which makes MCNTs suspension remain constant around its Curie temperature. These experiments demonstrate the self-regulating nature of MCNTs and self-regulating temperature around $43{ }^{\circ} \mathrm{C}$, meet the requirement for hyperthermia.

Fig. 4d shows the dispersed states of MNPs and MCNTs in aqueous media at the moment of dispersion and after $\sim 12 \mathrm{~h}$. Most MNPs precipitated after $12 \mathrm{~h}$ while MCNTs are still finely dispersed. The UV-vis spectra were performed to monitor dispersion of MNPs and MCNTs in aqueous media and the results are given in Fig. 1s. $\dagger$ The absorbance peak of MNPs decreased $65.2 \%$ after sedimentation for $12 \mathrm{~h}$, which is almost 5 times higher than MCNTs. Compared with MNPs, MCNTs have a better dispersibility. MNPs with great surface energy and the magnetic force have strong tendency to aggregate together. This is because the gravity of aggregate is stronger than the dispersive effect caused by Brownian motion. For MCNTs, the carboxylic groups on nanotube surface are negatively charged, which enable the MCNTs to repel from each other and keep the solution dispersed. MCNTs with a better dispersibility may avoid the inhomogeneous temperature distribution caused by the aggregation of MNPs in magnetic hyperthermia.

Another concern about the medical application is the biocompatibility of MCNTs. In clinical trials, nanoparticles are injected into tumor regions and most of them are allocated in tumor tissue, which resulted in the several times higher uptake of nanoparticles in tumor than that in normal tissue. Only 2.7$10 \%$ nanoparticles could be detected in other normal tissue even after 10 days' treatment. ${ }^{\mathbf{4 1 , 4 2}}$ After blood circulation and metabolism, the concentration of nanoparticles stay in normal tissue is low. For many cytotoxicity studies of hyperthermia, 100 $\mu \mathrm{g} \mathrm{ml} \mathrm{m}^{-1}$ is considered as a very high concentration of nanoparticles that can extravasate into normal tissue. ${ }^{\mathbf{4 3 4 4}}$ Therefore, here we also select $100 \mu \mathrm{g} \mathrm{ml}{ }^{-1}$ for cytotoxicity studies.

The cytotoxicity effect of MCNTs with the concentrations of $0 \mu \mathrm{g} \mathrm{ml} l^{-1}, 6.25 \mu \mathrm{g} \mathrm{ml}{ }^{-1}, 12.5 \mu \mathrm{g} \mathrm{ml}^{-1}, 25 \mu \mathrm{g} \mathrm{ml}^{-1}, 50 \mu \mathrm{g} \mathrm{ml} \mathrm{g}^{-1}$ and $100 \mu \mathrm{g} \mathrm{ml}^{-1}$ on HaCaT cells was examined after co-culture of $24 \mathrm{~h}, 48 \mathrm{~h}$ and $72 \mathrm{~h}$. As shown in Fig. 5a, the viability of HaCaT
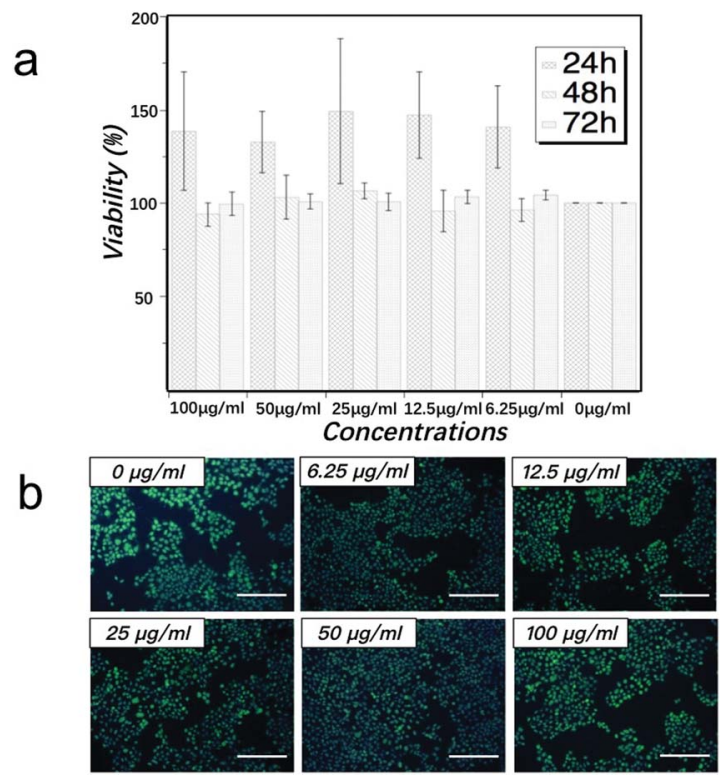

Fig. 5 Effects of MCNTs on the viability of HaCaT cells: (a) cell viability was assessed by CCK- 8 assay at $24 \mathrm{~h}, 48 \mathrm{~h}$ and $72 \mathrm{~h}$ after co-culture with various concentrations of MCNTs. Values were represented as the percentages of cell viability compared with that of the control group and expressed as means \pm standard deviation of triplicate determinations. (b) Representative fluorescent images of detached $\mathrm{HaCaT}$ cells which are triple stained with Calcein-AM (green), PI (red) and Hochest (blue) after co-culture with various concentrations of MCNTs for $72 \mathrm{~h}$. Scale bar: $50 \mu \mathrm{m}$ 
cells in all MCNTs concentrations are above $85 \%$, and there is no significant difference in cell viability between all MCNTs groups and control group ( $p$-value $>0.05$ ) after co-culture of $48 \mathrm{~h}$ and $72 \mathrm{~h}$. After co-culture of $24 \mathrm{~h}$, all MCNTs groups show some enhancement of cell viability. The similar phenomenon has also been observed in the cytotoxicity assay of gold nanoparticles and the enhanced growth of cell may be related to the receptor-mediated control of cell membranes. ${ }^{45,46}$ The more detailed mechanism is still under investigation.

In order to have more visualized observation of cell state, live-dead fluorescent microscopic analysis was performed. After co-culture with MCNTs for $72 \mathrm{~h}$, cells were stained with CalceinAM, PI and Hochest 33258. Dead cells can be identified by a red fluorescence generated by PI after intercalating into DNA, which only occurs after the entrance of the dead cell-permeable dye to the cell membrane. Cell nucleus can be identified by a blue fluorescence generated by Hochest 33258 after the binding of this living cell-permeable dye to DNA. Living cells can be identified by a green fluorescence generated by the enzymatic hydrolysis of Calcein-AM, which only takes place in living cells as a result of esterase activity. As can be seen in Fig. 5b, cells cocultured with all concentrations of MCNTs for $72 \mathrm{~h}$ show calcein-positive, Hochest 33258-positive and PI-negative state. This live-dead result is consistent with the quantitative CCK-8 assay in Fig. 5a. These results show that the MCNTs have low cytotoxicity for HaCaT in vitro under the concentrations of 6.25 $\mu \mathrm{g} \mathrm{ml} \mathrm{m}^{-1}$ to $100 \mu \mathrm{g} \mathrm{ml} \mathrm{m}^{-1}$. As cytotoxicity test is a quite complex systematic work, we will continue in-depth studies for other cell lines.

\section{Conclusions}

Magnetic carbon nanotubes with a Curie temperature of $45.7^{\circ} \mathrm{C}$ for self-regulating temperature hyperthermia were prepared through combining carboxyl carbon nanotubes and nanoparticles using hydrothermal method. Nanoparticles were successfully decorated on the surface of CNTs. The carboxylic groups on CNTs and the formation and hydration of CoO played important roles in the mechanisms of MCNTs formation, heterogeneous or homogeneous nucleation processes. MCNTs also show a better dispersibility than MNPs, which may avoid the inhomogeneous temperature distribution caused by the aggregation of nanoparticles in magnetic hyperthermia. The Curie temperature of MCNTs is $43{ }^{\circ} \mathrm{C}$ while the temperature of MCNTs suspension can be self-regulated at $42.7^{\circ} \mathrm{C}$ under the clinically used magnetic fields, which is suitable for selfregulating temperature hyperthermia. The evaluation of in vitro cytotoxicity of MCNTs also suggests low toxicity under the concentrations of $6.25 \mu \mathrm{g} \mathrm{ml} \mathrm{m}^{-1}$ to $100 \mu \mathrm{g} \mathrm{ml} \mathrm{m}^{-1}$. This study proposed a methodology on the bespoke synthesis of magnetic carbon nanotube for self-regulating hyperthermia, which may lead to further research on loading drugs for multi-modal cancer therapy.

\section{Conflicts of interest}

There are no conflicts to declare.

\section{Acknowledgements}

This work was supported by the National Natural Science Foundation of China [11572080, 51775541, 11772086]; the Natural Science Foundation of Liaoning Province [2015020198]; Fundamental Research Funds for the Central Universities [DUT17ZD229] and China Scholarship Council.

\section{References}

1 R. K. Gilchrist, R. Medal, W. D. Shorey, R. C. Hanselman, J. C. Parrott and C. B. Taylor, Ann. Surg., 1957, 146, 596-606.

2 T. Sadhukha, T. S. Wiedmann and J. Panyam, Biomaterials, 2013, 34, 5163-5171.

3 S. Ruta, R. Chantrell and O. Hovorka, Sci. Rep., 2015, 5, 9090. 4 A. Jordan, R. Scholz, P. Wust, H. Fähling and R. Felix, J. Magn. Magn. Mater., 1999, 201, 413-419.

5 K. Overgaard and J. Overgaard, Eur. J. Cancer, 1972, 8, 65-78. 6 M. Hiraoka, S. Jo, K. Akuta, Y. Nishimura, M. Takahashi and M. Abe, Cancer, 1987, 60, 121-127.

7 S. Iijima, Nature, 1991, 354, 56.

8 R. H. Baughman, A. A. Zakhidov and W. A. De Heer, Science, 2002, 297, 787-792.

9 A. Javey, J. Guo, Q. Wang, M. Lundstrom and H. Dai, Nature, 2003, 424, 654.

10 P. Kesharwani, V. Gajbhiye and N. K. Jain, Biomaterials, 2012, 33, 7138-7150.

11 Y. X. Zhao, A. Shaw, X. Zeng, E. Benson, A. M. Nyström and B. Högberg, ACS Nano, 2012, 6, 8684-8691.

12 S. Ji, C. Liu, B. Zhang, F. Yang, J. Xu, J. Long, C. Jin, D. Fu, Q. Ni and X. Yu, Biochim. Biophys. Acta, Rev. Cancer, 2010, 1806, 29-35.

13 Z. Liu, K. Chen, C. Davis, S. Sherlock, Q. Cao, X. Chen and H. Dai, Cancer Res., 2008, 68, 6652-6660.

14 A. Bianco, K. Kostarelos, C. D. Partidos and M. Prato, Chem. Commun., 2005, 5, 571-577.

15 A. Elhissi, W. Ahmed, I. U. Hassan, V. R. Dhanak and A. D'Emanuele, J. Drug Delivery, 2012, 2012, 837327.

16 S. Y. Madani, N. Naderi, O. Dissanayake, A. Tan and A. M. Seifalian, Int. J. Nanomed., 2011, 6, 2963.

17 P. Chakravarty, R. Marches, N. S. Zimmerman, A. D. E. Swafford, P. Bajaji, I. H. Musselman, P. Pantano, R. K. Draper and E. S. Vitetta, Proc. Natl. Acad. Sci. U.S.A, 2008, 105, 8697-8702.

18 Y. Matsuzaki, M. Edagawa, T. Shimizu, M. Hara, M. Tomita, T. Ayabe and T. Onitsuka, The Annals of Thoracic Surgery, 2004, 78, 1769-1772.

19 W. Rao and Z. S. Deng, CRC Crit. Rev. Bioeng., 2010, 38, 1.

20 A. Al Faraj, A. P. Shaik and A. S. Shaik, Int. J. Nanomed., 2015, 10, 157.

21 J. H. Choi, F. T. Nguyen, P. W. Barone, D. A. Heller, A. E. Moll, D. Patel, S. A. Boppart and M. S. Strano, Nano Lett., 2007, 7, 861-867.

22 S. Vasseur, E. Duguet, J. Portier, G. Goglio, S. Mornet, E. Hadová, K. Knížek, M. Maryško, P. Veverka and E. Pollert, J. Magn. Magn. Mater., 2006, 302, 315-320. 
23 M. Soleymani, M. Edrissi and A. M. Alizadeh, J. Mater. Chem. $B$, 2017, 5, 4705-4712.

24 M. Ebrahimi, J. Magn. Magn. Mater., 2016, 416, 134-140.

25 M. H. Alnasir, M. S. Awan and S. Manzoor, J. Magn. Magn. Mater., 2018, 449, 137-144.

26 M. Johannsen, U. Gneveckow, B. Thiesen, K. Taymoorian, C. H. Cho, N. Waldöfner, R. Scholz, A. Jordan, S. A. Loening and P. Wust, Eur. Urol., 2007, 52, 1653-1662.

27 K. Maier-Hauff, F. Ulrich, D. Nestler, H. Niehoff, P. Wust, B. Thiesen, H. Orawa, V. Budach and A. Jordan, J. NeuroOncol., 2011, 103, 317-324.

28 Q. Liu, J. Tian, W. Cui, P. Jiang, L. Cheng, A. M. Asiri and X. Sun, Angew. Chem., 2014, 126, 6828-6832.

29 N. F. Andrade, T. L. Vasconcelos, C. P. Gouvea, B. S. Archanjo, C. A. Achete, Y. A. Kim, M. Endo, C. Fantini, M. S. Dresselhaus and A. G. S. Filho, Carbon, 2015, 90, 172-180.

30 M. A. G. Soler, T. F. O. Melo, S. W. Da Silva, E. C. D. Lima, A. C. M. Pimenta, V. K. Garg, A. C. Oliveira and P. C. Morais, J. Magn. Magn. Mater., 2004, 272, 2357-2358.

$31 \mathrm{~W}$. Zhang, X. Zuo, D. Zhang, C. Wu and S. R. P. Silva, Nanotechnology, 2016, 27, 245707.

32 A. Pradeep, P. Priyadharsini and G. Chandrasekaran, J. Magn. Magn. Mater., 2008, 320, 2774-2779.

33 Y. Liu and L. Gao, Carbon, 2005, 43, 47-52.

34 C. Qin, J. Shen, Y. Hu and M. Ye, Compos. Sci. Technol., 2009, 69, 427-431.
35 C. W. Tang, C. B. Wang and S. H. Chien, Thermochim. Acta, 2008, 473, 68-73.

36 V. I. Nikolaev and A. M. Shipilin, Phys. Solid State, 2003, 45, 1079-1080.

37 V. Datsyuk, M. Kalyva, K. Papagelis, J. Parthenios, D. Tasis, A. Siokou, I. Kallitsis and C. Galiotis, Carbon, 2008, 46, 833-840.

38 I. Hilger, K. Frühauf, W. Andrä, R. Hiergeist, R. Hergt and W. A. Kaiser, Academic Radiology, 2002, 9, 198-202.

39 M. Palihawadana-Arachchige, H. Nemala, V. M. Naik and R. Naik, J. Appl. Phys., 2017, 121, 023901.

40 H. Nemala, J. S. Thakur, V. M. Naik, P. P. Vaishnava, G. Lawes and R. Naik, J. Appl. Phys., 2014, 116, 034309.

41 J. F. Hainfeld, D. N. Slatkin and H. M. Smilowitz, Phys. Med. Biol., 2004, 49, N309.

42 M. Johannsen, B. Thiesen, U. Gneveckow, K. Taymoorian, N. Waldöfner, R. Scholz, S. Deger, K. Jung, S. A. Loening and A. Jordan, Prostate, 2006, 66, 97-104.

43 A. Tomitaka, A. Hirukawa, T. Yamada, S. Morishita and Y. Katemura, J. Magn. Magn. Mater., 2009, 321, 1482-1484.

44 M. N. Nadagouda, A. B. Castle, R. C. Murdock, S. M. Hussain and R. S. Varma, Green Chem., 2010, 12, 114-122.

45 W. Cui, J. Li, Y. Zhang, H. Rong, W. Lu and L. Jiang, Nanomedicine, 2012, 8, 46-53.

46 W. J. Cui, W. S. Lu, Y. K. Zhang, G. H. Lin, T. X. Wei and L. Jiang, Colloids Surf., A, 2010, 358, 35-41. 